\title{
Epstein-Barr virus genetic variation in Vietnamese patients with nasopharyngeal carcinoma: full-length analysis of LMP1
}

Do Nguyen-Van · Ingemar Ernberg •

Phi Phan-Thi Phi · Chinh Tran-Thi ·

LiFu Hu

Published online: 27 August 2008

(C) Springer Science+Business Media, LLC 2008

\section{Erratum to: Virus Genes}

DOI 10.1007/s11262-008-0262-9

The publisher apologizes for the errors in this article that appeared in volume 37 , number 2 . The author Ingemar
Ernberg's last name should be spelled Ernberg, not Enrberg, as it appeared on the first page of the article.

The online version of the original article can be found under doi:10.1007/s11262-008-0262-9.

D. Nguyen-Van · I. Ernberg $\cdot$ LiF. Hu ( $ه)$

Department of Microbiology, Tumor and Cell Biology (MTC), Karolinska Institutet, P.O. Box 280, 17177 Stockholm, Sweden

e-mail: Lifu.Hu@ki.se

I. Ernberg

e-mail: Ingemar.Ernberg@ki.se

D. Nguyen-Van · P. Phan-Thi Phi · C. Tran-Thi

Department of Immuno-Pathophysiology, Hanoi Medical

University, Hanoi, Vietnam

e-mail: Do.Nguyen.Van@ki.se

P. Phan-Thi Phi

e-mail: phiphan_hmu@yahoo.com 